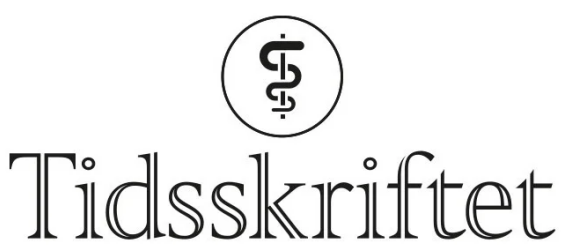

DEN NORSKE LEGEFORENING

\title{
Ventilasjonsstøtte for hypoksemiske intensivpasienter med covid-19
}

ORIGINALARTIKKEL

\section{TRINE GUNDEM}

trimagu@online.no

Avdeling for anestesiologi

Oslo universitetssykehus, Ullevål

Hun har bidratt med idé, utforming av studien, innsamling og tolkning av data, litteratursøk, utarbeiding/revisjon og godkjenning av innsendte manuskript.

Trine Marie Gundem er overlege.

Forfatteren har fylt ut ICMJE-skjemaet og oppgir ingen interessekonflikter.

\section{THERESA MARIERO OLASVEENGEN}

Avdeling for anestesiologi

Oslo universitetssykehus, Ullevål

og

Institutt for klinisk medisin

Universitetet i Oslo

Hun har bidratt med design, datainnsamling. tolkning av data, revisjon og godkjenning av innsendte manuskript.

Theresa Mariero Olasveengen er overlege og professor.

Forfatteren har fylt ut ICMJE-skjemaet og oppgir ingen interessekonflikter.

\section{KNUT ERIK HOVDA}

Akuttmedisinsk avdeling

og

CBRNE-senteret

Oslo universitetssykehus, Ullevål

Han har bidratt med utforming, gjennomføring, revisjon og godkjenning av innsendte manuskript. Knut Erik Hovda er overlege.

Forfatteren har fylt ut ICMJE-skjemaet og oppgir ingen interessekonflikter.

\section{KNUT GAUSTAD}

Avdeling for anestesiologi

Oslo universitetssykehus, Ullevål

Han har bidratt med datahåndtering, design, revisjon og godkjenning av innsendte manuskript.

Knut Gaustad er overlege.

Forfatteren har fylt ut ICMJE-skjemaet og oppgir ingen interessekonflikter.

\section{CHRISTINA SCHØNDORF}

Avdeling for anestesiologi

Oslo universitetssykehus, Ullevål 
Hun har bidratt med design, revisjon og godkjenning av innsendte manuskript. Christina Schøndorf er overlege.

Forfatteren har fylt ut ICMJE-skjemaet og oppgir ingen interessekonflikter.

\section{MORTEN ROSTRUP}

Akuttmedisinsk avdeling

Oslo universitetssykehus, Ullevål

og

Institutt for medisinske basalfag

Universitetet i Oslo

Han har bidratt med design, revisjon og godkjenning av innsendte manuskript.

Morten Rostrup er overlege og professor.

Forfatteren har fylt ut ICMJE-skjemaet og oppgir ingen interessekonflikter.

\section{STEN FRØYSHOV}

Akuttmedisinsk avdeling

Oslo universitetssykehus, Ullevål

Han har bidratt med design, revisjon og godkjenning av innsendte manuskript.

Sten Frøyshov er overlege.

Forfatteren har fylt ut ICMJE-skjemaet og oppgir ingen interessekonflikter.

\section{ØYSTEIN UNDSETH}

Akuttmedisinsk avdeling

Oslo universitetssykehus, Ullevål

Han har bidratt med design, revisjon og godkjenning av innsendte manuskript.

Øystein Undseth er overlege.

Forfatteren har fylt ut ICMJE-skjemaet og oppgir ingen interessekonflikter.

\section{KRISTIAN TONBY}

Infeksjonsmedisinsk avdeling

Oslo universitetssykehus, Ullevål

og

Institutt for klinisk medisin

Universitetet i Oslo

Han har bidratt med innsamling og tolkning av data, revisjon og godkjenning av innsendte manuskript.

Kristian Tonby er overlege og førsteamanuensis.

Forfatteren har fylt ut ICMJE-skjemaet og oppgir ingen interessekonflikter.

\section{ALEKSANDER RYGH HOLTEN}

Akuttmedisinsk avdeling

Oslo universitetssykehus, Ullevål

og

Institutt for klinisk medisin

Universitetet i Oslo

Han har bidratt med innsamling og tolkning av data, design, revisjon og godkjenning av innsendte manuskript.

Aleksander Rygh Holten er overlege og forsker/postdoktor.

Forfatteren har fylt ut ICMJE-skjemaet og oppgir ingen interessekonflikter.

\section{KJETIL SUNDE}

Avdeling for anestesiologi

Oslo universitetssykehus, Ullevål

og

Institutt for klinisk medisin

Universitetet i Oslo

Han har bidratt med utforming av studien, innsamling og tolkning av data, litteratursøk, design og revisjon, utarbeiding og godkjenning av innsendte manuskript.

Kjetil Sunde er overlege og professor.

Forfatteren har fylt ut ICMJE-skjemaet og oppgir ingen interessekonflikter. 
Covid-19-pneumoni kan gi alvorlig hypoksemisk respirasjonssvikt som krever intensivmedisinsk behandling. Vi ønsket å beskrive covid-19-intensivpasienter som ble behandlet med og uten invasiv ventilasjonsstøtte.

\section{MATERIALE OG METODE}

Materialet er hentet fra lokalt kvalitetsregister og består av data om pasienter med covid-19 innlagt på intensivavdelingen ved Oslo universitetssykehus, Ullevål i perioden 5.328.5.2020. Pasientene ble kategorisert i tre grupper basert på respirasjonssviktbehandlingen (oksygen alene, tillegg av ikke-invasiv ventilasjonsstøtte (NIV) og intubasjon/respirator) og beskrevet med deskriptiv statistikk.

\section{RESULTATER}

Av 165 innlagte covid-19-pasienter ble 26 (16\%) behandlet ved vår intensivavdeling. Fire av disse hadde behandlingsbegrensninger og ble ekskludert. De 22 pasientene inkludert i denne studien hadde gjennomsnittsalder 56 år (spredning 25-78 år), 17 (77\%) var menn. Elleve pasienter fikk respiratorbehandling, syv oksygen på maske og fire tillegg av ikkeinvasiv ventilasjonsstøtte. I respiratorgruppen var to døde per 28.5.2020, resten var skrevet ut av intensivavdelingen i live, hvorav én fortsatt lå på sengepost. Alle pasienter behandlet med oksygen og ikke-invasiv ventilasjonsstøtte var i live og utskrevet fra sykehus.

\section{FORTOLKNING}

Mange pasienter med covid-19-respirasjonssvikt og behov for intensivbehandling kan klare seg med økt oksygentilbud og ikke-invasiv ventilasjonsstøtte, men behov for intubasjon må fortløpende vurderes. Over $90 \%$ av aktivt behandlede intensivpasienter overlevde.

\section{HOVEDFUNN}

Blant de første 22 aktivt behandlede covid-19-pasientene på intensivavdelingen ved Oslo universitetssykehus, Ullevål, er den foreløpige dødeligheten på $9 \%$.

Halvparten av pasientene ble ikke intubert og respiratorbehandlet, selv om de hadde alvorlig hypoksemi og symptomer på akutt lungesvikt.

Covid-19-pandemien har ført til en stor belastning på vårt helsevesen. En rekke pasienter har blitt sykehusinnlagt, og de dårligste har blitt behandlet på intensivavdelinger. Det er primært når lungene angripes og pasienten utvikler alvorlig hypoksemi at intensivbehandling med ventilasjonsstøtte blir aktuelt. Det kom tidlig internasjonale rapporter om rask utvikling av akutt lungesviktsyndrom (acute respiratory distress syndrome, ARDS) som nødvendiggjorde tidlig intubasjon og invasiv respiratorbehandling $(\underline{1}, \underline{2})$. Akutt lungesviktsyndrom defineres med Berlin-kriteriene avhengig av grad av hypoksemi målt med $\mathrm{PaO}_{2} / \mathrm{FiO}_{2}$-ratio med positivt endeekspiratorisk trykk (PEEP) $>5 \mathrm{~cm}$ $\mathrm{H}_{2} \mathrm{O}$, akutt debut og bilaterale lungefortetninger og respirasjonssvikt som ikke kan forklares av hjertesvikt eller overvæsking alene (3). Blant covid-19-pasientene var langvarig og komplisert lungebeskyttende respiratorbehandling beskrevet, med bruk av høyt positivt endeekspiratorisk trykk opp mot 14-16 $\mathrm{cm} \mathrm{H}_{2} \mathrm{O}(\underline{2})$.

Oksygentilførsel til hypoksemiske pasienter kan imidlertid også gis alene på maske eller kombinert med ikke-invasiv ventilasjonsstøtte (NIV). Men, ikke-invasiv ventilasjonsstøtte har tidligere vist å ikke ha nytte og føre til mer komplikasjoner hos lignende pasienter (4). Italienske kolleger rapporterte også samme erfaringer med sine covid-19-pasienter (므). Det er foreløpig ingen konsensus om nytte eller risiko for aerosolgenerering ved ikke-invasiv 
ventilasjonsstøtte eller nasal high flow-oksygen hos covid-19-pasienter (5, 6 ). Dessuten diskuteres hvorvidt alle hypoksemiske pasienter med covid-19-pneumoni utvikler akutt lungesviktsyndrom (7.).

I lys av nyere kunnskap vil vi dele våre erfaringer med håndteringen av de kritisk syke covid-19-pasientene som ble behandlet på vår intensivavdeling. Vi ønsket å kartlegge klinisk tilstand, behandling og utfall blant intensivpasienter som ble behandlet med og uten invasiv ventilasjonsstøtte.

\section{Materiale og metode}

Oslo universitetssykehus, Ullevål er lokalsykehus for flere av Oslos bydeler samt regionsykehus i Helse-Sør- $\emptyset$ st. Sykehuset har omkring 1200 senger, ca. 45000 innleggelser og mer enn 300 ooo polikliniske konsultasjoner årlig og er landets største akuttsykehus og traumesenter. Normalt er 33 intensivplasser med respiratorkapasitet for voksne pasienter tilgjengelig, fordelt på seks forskjellige intensiv- og overvåkningsavdelinger, men ikke sjelden er kapasiteten utvidet på grunn av høy aktivitet.

Grunnet forventninger om et stort antall intensivpasienter under pandemien ble det $\mathrm{i}$ begynnelsen av mars 2020 etablert tre intensivkohorter som var klare for å ta imot til sammen 33 intensivtrengende covid-19-pasienter samt fire undertrykksisolat reservert for spesielt aerosolgenererende prosedyrer. Det ble også opprettet en intermediær kohort, og flere av sengepostene på medisinsk avdeling fungerte som rene covid-19-sengeposter. Her var opptil 15 l oksygen på maske med reservoar tilgjengelig, mens det på intensivkohortene også var mulighet for ikke-invasiv ventilasjonsstøtte. På sengepostkohortene ble pasientene monitorert med National Early Warning Score (NEWS) (ㅁ), opptil 2-3 ganger per sykepleiervakt. Man hadde daglige møter mellom sengepost- og intensivleger med vurdering av hvorvidt pasientene skulle overflyttes til intensiv- eller intermediærkohort. Pasienter som ikke responderte tilfredsstillende på oksygenbehandlingen og som hadde økende tegn på slitenhet/utmattelse med raskere respirasjonsfrekvens og takykardi, ble innlagt på intensivavdelingen. Det var ingen universelle kriterier, men dette ble besluttet av vaktlegen på sengepost eller i akuttmottak og ansvarlig intensivlege.

For å ivareta behandlingen på intensivkohortene ble det laget nye vaktteam bestående av intensiv- og anestesileger fra Akuttklinikken og Akuttmedisinsk avdeling. Behandlingen skulle primært følge retningslinjer for akutt lungesviktsyndrom, med lungebeskyttende ventilasjon med lavt tidevolum (4-6 ml/kg predikert kroppsvekt), platåtrykk $<30 \mathrm{~cm} \mathrm{H}_{2} \mathrm{O}$, drivtrykk $<15 \mathrm{~cm} \mathrm{H}_{2} \mathrm{O}$ og PEEP $>5 \mathrm{~cm} \mathrm{H}_{2} \mathrm{O}$. I tillegg kommer dyp sedasjon, om nødvendig nevromuskulær blokade, restriktiv væsketilførsel og lav terskel for bukleie $(9, \underline{10})$. Imidlertid la vi også opp til individuelle tilpasninger. Dette innebar at noen pasienter eventuelt kunne tilbys ikke-invasiv ventilasjonsst $\varnothing t t e$, da med PEEP $5-8 \mathrm{~cm} \mathrm{H}_{2} \mathrm{O}$, men med lavest mulig trykkstøtte etter behov og respons. Pasienter som ikke responderte tilfredsstillende på oksygen, var dermed aktuelle for NIV-behandling, som ble besluttet av ansvarlig intensivlege. Tegn på utmattelse etter langvarig hypoksemi (rask og stadig $\varnothing$ kende respirasjonsfrekvens, takykardi, subjektivt uttrykk for slitenhet, fallende $\mathrm{PaO}_{2}$ til tross for $\varnothing$ kende oksygentilbud, $\varnothing$ kende $\mathrm{PaCO}_{2}$ ) var intubasjonskriterium.

\section{DATAINNHENTING OG -PRESENTASJON}

Alle pasienter som legges inn ved Oslo universitetssykehus med covid-19, registreres fortløpende i et lokalt kvalitetsregister parallelt med registrering i Norsk pandemiregister. Det interne kvalitetsregisteret samt denne publikasjonen av data fra registeret er godkjent av lokalt personvernombud (saksnummer 20/o7119). Beskrivelse av sykdomsforløp og behandling for alle pasientene innlagt ved intensivavdelingen ved Ullevål i perioden 5.328.5.2020 ble levert av det interne kvalitetsregisteret. Tre av medforfatterne (TMO, KT, ARH) tok initiativet til dette registeret og har full tilgang til dataene. 
Det interne kvalitetsregisteret inkluderer parameterne som leveres til det nasjonale pandemiregisteret i tillegg til ytterligere informasjon om komorbiditet, daglige opplysninger om pasientstatus (blodtrykk, puls, oksygenmetning, mental påvirkning), pasientbehandling (antimikrobiell behandling og organstøttende behandling som f.eks. respirasjons- og sirkulasjonsstøtte) samt resultater fra biokjemiske og radiologiske undersøkelser. Innleggelsestidspunkt og tidspunkt for overflytninger mellom avdelinger registreres, og døgn telles fra midnatt til midnatt.

Oppsummering av parametere relatert til innkomststatus, intensivbehandling av respirasjonssvikt og utfall ble brukt i denne publikasjonen. Utover velkjente kliniske parametre ble også flere aktuelle skåringsverktøy brukt. For å karakterisere pasienten generelt brukte vi Charlson Comorbidity Index (predikerer dødelighet basert på komorbiditet, o-37 poeng) og Clinical Frailty Scale (predikerer grad av skrøpelighet, fra frisk (1 poeng) til terminal (9 poeng), basert på kognitiv status, mobiliseringsevne samt hjelpebehov rett forut for akutt sykdom). Som et mål for fysiologisk status ved innleggelsen i akuttmottak brukte vi NEWS (respirasjonsfrekvens, perifer oksygenmetning, systolisk blodtrykk, pulsfrekvens, bevissthetsnivå/forvirring og temperatur som alle skåres fra 1 til 3 poeng; NEWS $\geq 5$ indikerer alvorlig akutt sykdom) og Quick Sequential Organ Failure Assessment (qSOFA) (gir ett poeng hver for respirasjonsfrekvens $\geq 22 / \mathrm{min}$, systolisk blodtrykk $\leq 100 \mathrm{~mm} \mathrm{Hg}$ og endret mental status monitorert med Glasgow Coma Scale $(G C S) \leq 15 ;$ qSOFA $2 o_{3}$ indikerer alvorlig sykdom). SOFA-skår angir den mest avvikende verdien for henholdsvis sirkulasjon, respirasjon, nyrefunksjon, mental status (målt med GCS), koagulasjon og leverfunksjon, og ble i denne studien brukt for å karakterisere alvorligheten av sykdommen ved ankomst til akuttmottak samt den dårligste skåren totalt sett under hele oppholdet.

Kun pasienter som ble innlagt på intensivkohortene, er registrert som intensivpasienter og dermed inkludert i studien. Pasientene er delt inn i tre grupper basert på behandling av respirasjonssvikt (oksygen alene, tillegg av ikke-invasiv ventilasjonsstøtte og intubasjon med bruk av respirator) og beskrevet med deskriptiv statistikk (antall med prosent og gjennomsnitt med største og minste verdi). Det er ikke gjort statistisk sammenlikning av gruppene.

\section{Resultater}

I perioden ble 165 covid-19-pasienter innlagt på Oslo universitetssykehus, Ullevål. Blant disse ble $26(16 \%)$ behandlet på en av intensivkohortene. Fire av disse hadde behandlingsbegrensninger på grunn av betydelig komorbiditet, høy alder og skrøpelighet. De var derfor ikke aktuelle for invasiv respiratorbehandling og er ekskludert fra studien (figur 1). Av de 22 inkluderte pasientene fikk 11 respiratorbehandling (to av disse fikk initialt ikke-invasiv ventilasjonsst $\varnothing t t e), 7$ kun oksygen og 4 tillegg av ikke-invasiv ventilasjonsst $\varnothing t t e$ (figur 1, tabell 1). Gjennomsnittsalderen var 56 år (spredning 25-78 år), og 17 (77\%) var menn. Pasientene hadde totalt sett lite komorbiditet, med en gjennomsnittlig Charlson Comorbidity Index på 1 (spredning o-3), men ni av pasientene hadde hjertesykdom/hypertensjon. Gjennomsnittlig kroppsmasseindeks var 30-35 i alle grupper (tabell 1). 


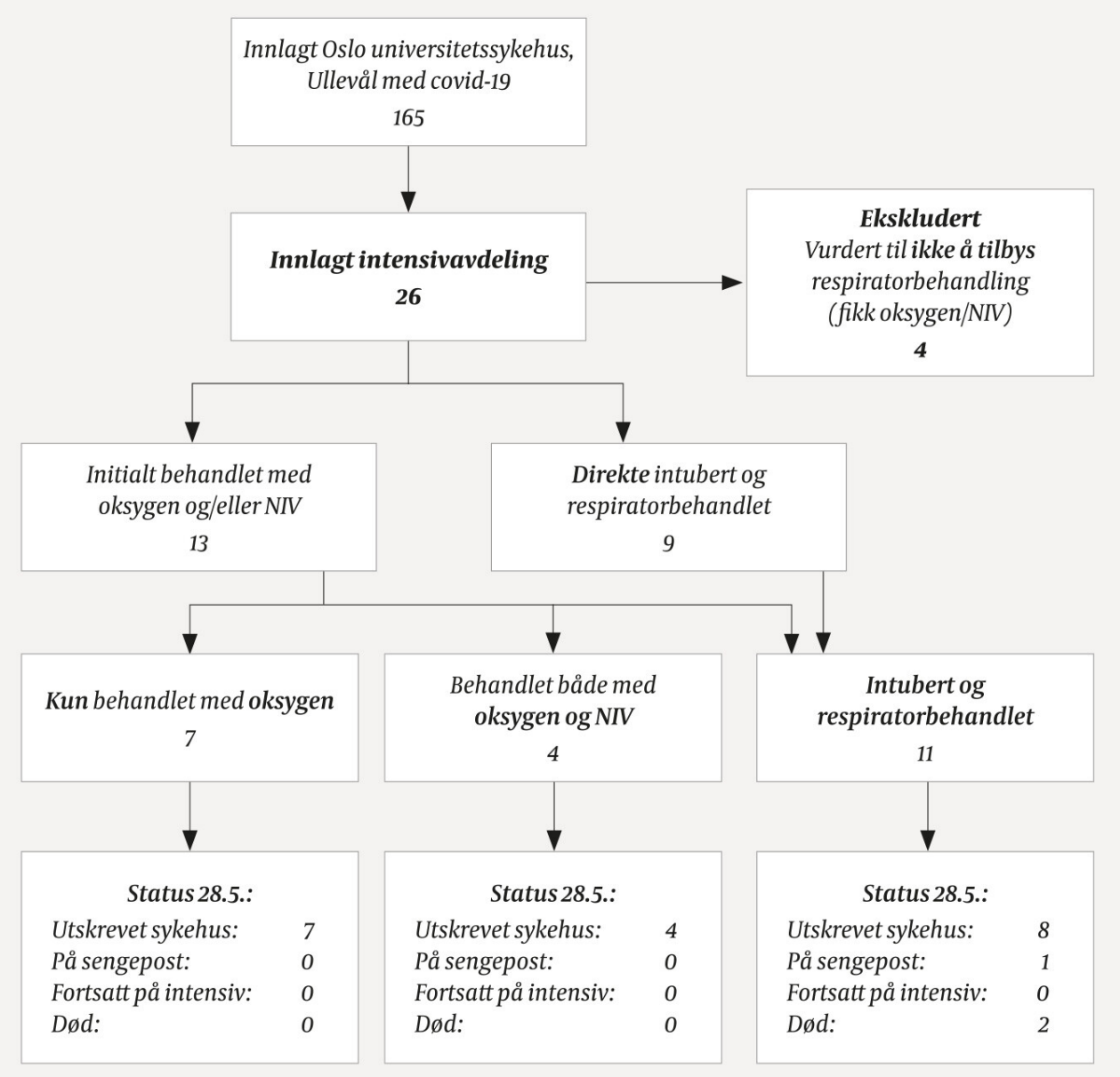

Figur 1 Oversikt over alle covid-19-pasienter innlagt på Oslo universitetssykehus, Ullevål i perioden 5.3-28.5.2020. NIV= ikke-invasiv ventilasjonsstøtte.

\section{Tabell 1}

Aktivt behandlede covid-19-pasienter på intensivavdelingen, Oslo universitetssykehus, Ullevål i perioden 5.3-28.5.2020. Pasientkarakteristika etter gitt behandling. Kontinuerlige variabler presenteres som gjennomsnitt (spredning). For kategoriske variabler angis antall i hver gruppe. SOFA= Sequential Organ Failure Assessment, qSOFA = Quick-SOFA, NEWS = National Early Warning Score, $\mathrm{SpO}_{2}=$ surstoffmetning, $\mathrm{PaO}_{2}=$ oksygens partialtrykk i arterieblod, $\mathrm{FiO}_{2}=$ fraksjon av inspirert oksygen .

\begin{tabular}{|c|c|c|c|c|}
\hline & $\begin{array}{l}\text { Alle } \\
(\mathrm{N}=\mathbf{2 2})\end{array}$ & $\begin{array}{l}\text { Oksygen } \\
(\mathbf{n}=7)\end{array}$ & $\begin{array}{l}\text { Ikke-invasiv } \\
\text { ventilasjonsstøtte } \\
(n=4)\end{array}$ & $\begin{array}{l}\text { Respirator } \\
(\mathbf{n}=\mathbf{1 1})\end{array}$ \\
\hline \multicolumn{5}{|l|}{ Pasientkarakteristika } \\
\hline Alder (år) & $\begin{array}{r}59(25- \\
78)\end{array}$ & $52(25-76)$ & $70(55-78)$ & $58(43-74)$ \\
\hline Menn & 17 & 5 & 4 & 8 \\
\hline $\begin{array}{l}\text { Kroppsmasseindeks }\left(\mathrm{kg} / \mathrm{m}^{2}\right)^{1} \\
(\text { overvekt }>25, \text { fedme }>30)\end{array}$ & $\begin{aligned} 30(24- \\
51)\end{aligned}$ & $32(25-51)$ & $31(27-36)$ & $30(24-35)$ \\
\hline $\begin{array}{l}\text { Charlson Comorbidity Index } \\
(0-37 \text { poeng) }\end{array}$ & $1(0-4)$ & $1(0-4)$ & $2(0-4)$ & $1(0-3)$ \\
\hline
\end{tabular}




\begin{tabular}{|c|c|c|c|c|}
\hline & $\begin{array}{l}\text { Alle } \\
(\mathrm{N}=\mathbf{2 2})\end{array}$ & $\begin{array}{l}\text { Oksygen } \\
(\mathbf{n}=7)\end{array}$ & $\begin{array}{l}\text { Ikke-invasiv } \\
\text { ventilasjonsstøtte } \\
(n=4)\end{array}$ & $\begin{array}{l}\text { Respirator } \\
(\mathbf{n}=\mathbf{1 1})\end{array}$ \\
\hline $\begin{array}{l}\text { Clinical Frailty Scale (1- } \\
9 \text { poeng) }\end{array}$ & $3(2-4)$ & $3(2-4)$ & $3(2-4)$ & $3(2-4)$ \\
\hline \multicolumn{5}{|l|}{ Status i akuttmottak } \\
\hline SOFA (0-24 poeng) & $3(0-7)$ & $3(0-7)$ & $3(2-3)$ & $4(1-7)$ \\
\hline qSOFA (0-3 poeng) & $1(0-2)$ & $1(0-2)$ & $1(1-1)$ & $1(0-2)$ \\
\hline NEWS (0-20 poeng) & $8(1-14)$ & $8(3-14)$ & $9(8-11)$ & $9(1-13)$ \\
\hline $\begin{array}{l}\text { Endret mental status (antall } \\
\text { med endring i Glasgow Coma } \\
\text { Scale, GSC) }\end{array}$ & 5 & 3 & 0 & 2 \\
\hline $\begin{array}{l}\text { Middel arterietrykk (MAP) } \\
(\mathrm{mm} \mathrm{Hg})\end{array}$ & $\begin{array}{r}96(68- \\
132)\end{array}$ & $\begin{array}{r}93(73- \\
104)\end{array}$ & $96(68-132)$ & $98(74-118)$ \\
\hline$\varnothing$ retemperatur $\left({ }^{\circ} \mathrm{C}\right)$ & $\begin{array}{r}38,3 \\
(36,0- \\
40,3)\end{array}$ & $\begin{array}{r}38,1(36,0- \\
39,4)\end{array}$ & $38,8(37,7-39,5)$ & $\begin{array}{r}38,2(36,4- \\
40,3)\end{array}$ \\
\hline $\begin{array}{l}\text { Respirasjonsfrekvens (12- } \\
16 \text { pust/min) }\end{array}$ & $\begin{array}{r}33(20- \\
52)\end{array}$ & $29(20-40)$ & $35(23-45)$ & $36(20-52)$ \\
\hline $\mathrm{SpO}_{2}^{6}(95-99 \%)$ & $\begin{array}{r}87(56- \\
100)\end{array}$ & $\begin{array}{r}88(56- \\
100)\end{array}$ & $90(86-95)$ & $85(57-98)$ \\
\hline $\mathrm{PaO}_{2}^{7}(10,5-14 \mathrm{kPa})$ & $\begin{array}{r}8,0(4,0- \\
12,8)\end{array}$ & $\begin{array}{r}7,6(4,0- \\
11,8)\end{array}$ & $9,1(8,4-10,1)$ & $7,9(5,0-12,8)$ \\
\hline $\mathrm{PaO}_{2} / \mathrm{FiO}_{2}{ }^{8}$-ratio ${ }^{2}(55-65 \mathrm{kPa})$ & $\begin{array}{r}26(6- \\
56)\end{array}$ & $32(10-56)$ & $35(21-42)$ & $21(6-43)$ \\
\hline $\mathrm{CRP}(<5 \mathrm{mg} / \mathrm{l})$ & $\begin{array}{r}164(44- \\
483)\end{array}$ & $\begin{array}{r}143(44- \\
428)\end{array}$ & $139(86-194)$ & $188(47-483)$ \\
\hline Ferritin $(30-400 \mu \mathrm{g} / \mathrm{l})^{1}$ & $\begin{array}{r}1298 \\
(163-4 \\
994)\end{array}$ & $\begin{array}{r}1834(163- \\
4994)\end{array}$ & $717(178-1432)$ & $\begin{array}{r}1167(512-2 \\
821)\end{array}$ \\
\hline $\begin{array}{l}\text { D-dimer (mg/L FEU) } \\
\text { (aldersjusterte } \\
\text { beslutningsgrenser) }\end{array}$ & $\begin{array}{r}1,7(0,2- \\
>4)\end{array}$ & $\begin{array}{r}1,7(0,2-> \\
4)\end{array}$ & $1,6(0,7-2,6)$ & $2,0(0,5->4)$ \\
\hline Leukocytter $\left(3,5-10 \cdot 10^{9} / \mathrm{I}\right)$ & $\begin{array}{r}8,8(3,1- \\
17,2)\end{array}$ & $\begin{array}{r}7,1(3,1- \\
14,4)\end{array}$ & $8,1(5,7-11,3)$ & $10,3(5,0-17,2)$ \\
\hline Lymfocytter $\left(1,1-3,3 \cdot 10^{9} / I\right)^{1}$ & $\begin{array}{r}0,9(0,5- \\
1,8)\end{array}$ & $\begin{array}{r}0,9(0,7- \\
1,4)\end{array}$ & $0,9(0,5-1,5)$ & $0,9(0,6-1,8)$ \\
\hline Laktat $(0,5-2,2 \mathrm{mmol} / \mathrm{l})$ & $\begin{array}{r}1,7(0,7- \\
5,4)\end{array}$ & $\begin{array}{r}1,8(0,7- \\
4,7)\end{array}$ & $1,1(1,0-1,2)$ & $1,9(0,9-5,4)$ \\
\hline \multicolumn{5}{|l|}{ Behandling og utfall } \\
\hline $\begin{array}{l}\text { Dårligste SOFA-skår }{ }^{1} \text { (0- } \\
24 \text { poeng) }\end{array}$ & $6(2-10)$ & $4(2-6)$ & $7(4-9)$ & $8(6-10)$ \\
\hline $\begin{array}{l}\text { Tid fra innleggelse til } \\
\text { intensivbehandling (døgn) }\end{array}$ & $2(0-4)$ & $2(1-3)$ & $3(2-4)$ & $1(0-3)$ \\
\hline
\end{tabular}




\begin{tabular}{|c|c|c|c|c|}
\hline & $\begin{array}{l}\text { Alle } \\
(\mathrm{N}=\mathbf{2 2})\end{array}$ & $\begin{array}{l}\text { Oksygen } \\
(\mathbf{n}=7)\end{array}$ & $\begin{array}{l}\text { Ikke-invasiv } \\
\text { ventilasjonsstøtte } \\
(\mathrm{n}=4)\end{array}$ & $\begin{array}{l}\text { Respirator } \\
(\mathbf{n}=\mathbf{1 1})\end{array}$ \\
\hline $\begin{array}{l}\text { Tid fra innleggelse til } \\
\text { respirator (døgn) }\end{array}$ & - & - & - & $1(0-4)$ \\
\hline Liggetid respirator (døgn) & - & - & - & $22(9-49)$ \\
\hline $\begin{array}{l}\text { Liggetid intensivavdeling } \\
\text { (døgn) }\end{array}$ & $15(2-56)$ & $4(2-8)$ & $5(2-7)$ & $25(10-56)$ \\
\hline Liggetid sykehus (døgn) & $\begin{array}{r}23(6- \\
65)\end{array}$ & $14(6-24)$ & $15(12-18)$ & $32(17-65)$ \\
\hline $\begin{array}{l}\text { Utskrevet i live fra } \\
\text { intensivavdeling }\end{array}$ & $20^{3}$ & 7 & 4 & $9^{3}$ \\
\hline
\end{tabular}

${ }^{1}$ Kroppsmasseindeks mangler hos tre pasienter og ferritin, D-dimer og lymfocytter hos én pasient

${ }^{2} \mathrm{PaO}_{2} / \mathrm{FiO}_{2}$-ratio er et uttrykk for pasientens oksygenbehov

3Én pasient fortsatt innlagt på sykehus (sengepost)

Av de elleve pasientene i respiratorgruppen var to døde per 28.5.2020, mens resten var skrevet ut av intensivavdelingen i live, hvorav én pasient fortsatt lå på sengepost. Fire pasienter ble trakeotomert. Alle pasientene uten respiratorbehandling overlevde og er utskrevet fra intensivavdelingen. Vi har ikke hatt reinnleggelser til intensivavdelingen. Per 28.5.2020 var dødeligheten blant alle intensivpasientene som fikk aktiv behandling $9 \%$ (2/22) og blant respiratorbehandlede pasienter $18 \%$ (2/11) (figur 1, tabell 1 ).

De som ble intubert og respiratorbehandlet, synes å ha hatt lavere $\mathrm{PaO}_{2} / \mathrm{FiO}_{2}$-ratio ved innleggelsen i akuttmottak (tabell 1). Samtlige ble innlagt på intensivavdelingen i andre sykdomsuke, og tiden fra innleggelse i sykehus til intensivbehandling og intubasjon var o4 dager. Gjennomsnittlig liggetid på intensivavdelingen var henholdsvis 4, 5 og 25 dager for oksygen-, NIV- og respirator-pasientene (tabell 1 ). $\mathrm{Ni}$ av elleve respiratorpasienter ble lagt $\mathrm{i}$ mageleie. Ingen av pasientene med ikke-invasiv ventilasjonsst $\varnothing t t e$ ble lagt i klassisk mageleie, men hyppig snuing og mobilisering er en del av behandlingen for alle intensivpasienter, hvis mulig. Gjennomsnittlig liggetid på respirator var 22 dager (9-49). Begge som døde, fikk multiorgansvikt med hemodynamisk instabilitet.

\section{Diskusjon}

I denne rapporten om de første 22 aktivt behandlede covid-19-pasientene på

intensivavdelingen ved Oslo universitetssykehus, Ullevål, var dødeligheten $9 \%$. Halvparten av pasientene ble ikke intubert og respiratorbehandlet, selv om de hadde alvorlig hypoksemi og symptomer på akutt lungesvikt etter Berlin-kriteriene (3). Disse pasientene synes alle å ha hatt et bra utfall, med forholdsvis kort tid på intensivavdelingen. Andelen overvektige var påfallende høy blant intensivpasientene.

Gattinoni og medarbeidere diskuterer om respiratorbehandling med tradisjonell tilnærming til akutt lungesviktsyndrom i noen tilfeller kan gjøre mer skade enn nytte for covid-19-pasienter. De anbefaler en mer individualisert tilnærming basert på pasientenes fenotype, og har derfor delt pasientene inn i to grupper: fenotype $L$ med lite lungestivhet og nærmest normal ettergivbarhet (compliance) og fenotype $\mathrm{H}$ med $ø$ kende $ø$ dem, redusert gassvolum og betydelig lungestivhet med lav ettergivbarhet $(\underline{11}, \underline{12})$. Hos type Lpasientene forklares alvorlig hypoksemi med tap av både perfusjonsregulering og 
hypoksisk vasokonstriksjon. Andelen av sammenfalt lungevev er lavt, og potensialet for rekruttering begrenset. En respiratortilnærming med unødvendig høyt positivt endeekspiratorisk trykk hos disse pasientene synes derfor unødvendig $(\underline{11}, \underline{12})$. Initiale tiltak for disse pasientene kan være å øke oksygentilbudet med forskjellige maskesystemer eller

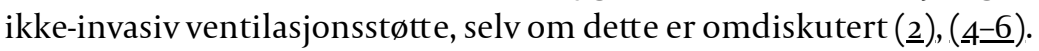

På våre sengepostkohorter fikk pasientene opptil 10-15 l oksygen per maske under nøye NEWS-monitorering, som ble skåret flere ganger per sykepleiervakt (ㅁ), og arterielle blodgasser på indikasjon. I tillegg til daglig møtevirksomhet tok legene på sengepost kontakt med intensivlegene ved behov, og ved økende respirasjonsbesvær/tegn på utmattelse ble pasientene overført til en intensivkohort. Flere av pasientene klarte seg allikevel videre med oksygen og forskjellige maskesystemer. Vi erfarte at til tross for klinisk og radiologisk alvorlig lungesvikt, var det mulig å gjennomføre intermitterende ikkeinvasiv ventilasjonsstøtte med suksess og dermed unngå intubasjon hos noen motiverte pasienter.

Det er viktig å understreke betydningen av kontinuerlig tilstedeværelse av erfarne intensivsykepleiere hos alle intensivpasienter, spesielt også hos selvpustende, hypoksemiske pasienter med oksygen på maske eller ikke-invasiv ventilasjonsstøtte. Aktiv mobilisering med hyppige leieendringer, fysioterapi og individualisert smertebehandling/sedasjon er en svært viktig tilleggsdel av denne intensivbehandlingen. Det er imidlertid viktig å understreke at en spontantpustende pasient med høy respiratorisk innsats og uttalt bruk av respirasjonsmuskulatur kan generere et betydelig negativt trykk i pleurahulen, med påfølgende høyt transpulmonalt trykk. Et høyt transpulmonalt trykk fører til større lungebelastning og risiko for forverring av pasientens lungesvikt (patient self-inflicted lung injury, P-SILI) (1ㅡ, 13). Pasientene må derfor overvåkes nøye med tanke på eventuell intubasjon.

I henhold til internasjonale erfaringer benyttet vi i tidlig fase av respiratorbehandlingen lave tidevolum, lavt platåtrykk, lavt drivtrykk, til dels høyt positivt endeekspiratorisk trykk (opp mot 14-16 $\mathrm{cm} \mathrm{H}_{2} \mathrm{O}$ ) og hyppig bukleie (ㅁ‥5, $\left.\underline{8}\right)(\underline{8-10})$. Dette til tross for at de fleste av pasientenes lunger hadde en tilnærmet normal ettergivbarhet $\left(>50 \mathrm{ml} / \mathrm{cm} \mathrm{H}_{2} \mathrm{O}\right.$ ). Vi erfarte etterhvert at positivt endeekspiratorisk trykk ofte kunne reduseres til 8-10 $\mathrm{cm} \mathrm{H}_{2} \mathrm{O}$ uten at oksygeneringen eller ettergivbarheten ble dårligere. Enkelte pasienter krevde imidlertid et økende eller vedvarende høyt positivt endeekspiratorisk trykk og gjentatt bukleie for å opprettolde en viss oksygenering. Man kan tenke seg at vi dermed hos noen pasienter så en utvikling fra fenotype L til $\mathrm{H}(\underline{11-13})$. Disse pasientene hadde omfattende lungeforandringer på CT, en stor andel ikke-ventilert lungevev og dermed større potensial for gevinst av høyere positivt endeekspiratorisk trykk og bukleie.

Gattinoni og medarbeideres teorier er tuftet på erfaringer med covid-19 samt tidligere forskning på akutt lungesvikt(syndrom) (7.), (11-13). Uansett passer deres beskrivelse av de to fenotypene godt med våre observasjoner. Vi mener derfor at man i mange tilfeller, selv med betydelig hypoksemi, kan avvente intubasjon dersom tilført oksygen alene, ikkeinvasiv ventilasjonsstøtte eller nasal high flow gir tilfredsstillende klinisk bedring og pasienten ikke er utmattet. Behov for intubasjon må imidlertid fortløpende vurderes, og etter intubasjon bør respiratorbehandlingen tilpasses pasientens lungefysiologi og kliniske tilstand.

Dette forutsetter et erfarent intensivpersonell 24 timer i døgnet med forståelse for lungefysiologi og avansert, skånsom respiratorbehandling og som tett kan følge opp ettergivbarhet, tidevolum, platåtrykk og titrering av positivt endeekspiratorisk trykk. Alt dette vil kanskje redusere risikoen for at fenotype $\mathrm{L}$ utvikler seg til fenotype $\mathrm{H}$ og livstruende hypoksemi $(\underline{11-13})$. Å skille mellom de to fenotypene hos den enkelte pasient er ikke nødvendigvis enkelt, og det vil være glidende overganger. CT-undersøkelse vil kunne være til hjelp, og vi anbefaler systematisk måling av statisk ettergivbarhet hos alle respiratorpasienter. 
Det er viktig å erkjenne at omfanget av denne sykdommen og pandemisituasjonen gjør at behandlingen må sees på som en dynamisk prosess hvor vi underveis er åpne for å endre kurs og strategi basert på egne og andres erfaringer og kunnskap.

\section{BEGRENSNINGER}

Den viktigste begrensningen er et totalt sett lavt antall pasienter, behandlet på kun ett sykehus. Dermed er muligheten for generaliserbarhet liten. Vi har ikke omtalt annen spesifikk behandling enn de forskjellige ventilasjons- og oksygeneringsstrategiene. Tiltak som sirkulasjonsstøtte, væskebehandling, tromboseprofylakse, antiviral-/antiinfektiv behandling, immunmodulerende terapi, immunrespons, ernæring, sedasjon/bruk av muskelrelakserende midler, generell multiorgansviktbehandling er ikke nærmere beskrevet. Dette kan selvfølgelig påvirke behandlingsutfallet. Vi omtaler heller ikke detaljer om respiratorinnstillinger og aktuelle verdier utover at vi tilstrebet lungebeskyttende ventilasjon med en surstoffmetning $\left(\mathrm{SaO}_{2}\right)$ på 88-92\%, og akseptering av forhøyet arteriell $\mathrm{CO}_{2}$ og moderat acidose. Primært ble trykk- eller volumkontrollert ventilasjon gjennomført, med overgang til trykkstøttet ventilasjon når klinisk status tilsa dette.

Målinger av lungenes ettergivbarhet hos respiratorbehandlede pasienter ble dessverre ikke systematisk registrert. Styring av respiratorbehandling etter måling av transpulmonalt trykk og $\mathrm{CO}_{2}$-sparende teknikker via dialysemaskin brukes ikke rutinemessig ved Ullevål. Gjennomsnittverdiene for D-dimer er sannsynligvis for lave, da høye verdier ble registrert, som $>4 \mathrm{mg} / \mathrm{l} \mathrm{FEU}$.

Med tanke på personvern og det lave antallet pasienter kan vi ikke gå inn på detaljer rundt håndtering av eller data vedrørende enkeltpasienter. Vi har heller ikke data vedrørende fysisk og mentalt funksjonsnivå hos pasienter som er utskrevet fra sykehus.

\section{Konklusjon}

Overlevelsen blant de 22 aktivt behandlede covid-19-intensivpasientene var høy, med $91 \%$. Mange selvpustende hypoksemiske covid-19-pasienter klarte seg med økt oksygentilbud og ikke-invasiv ventilasjonsstøtte.

Artikkelen er fagfellevurdert.

\section{LITTERATUR}

1. Wu F, Zhao S, Yu B et al. A new coronavirus associated with human respiratory disease in China. Nature 2020; 579: 265-9. [PubMed][CrossRef]

2. Grasselli G, Zangrillo A, Zanella A et al. Baseline characteristics and outcomes of 1591 patients infected with SARS-CoV-2 admitted to ICUs of the Lombardy Region, Italy. JAMA 2020;323: 1574-81. [PubMed][CrossRef]

3. Ranieri VM, Rubenfeld GD, Thompson BT et al. Acute respiratory distress syndrome: the Berlin Definition. JAMA 2012;307: 2526-33. [PubMed]

4. Alraddadi BM, Qushmaq I, Al-Hameed FM et al. Noninvasive ventilation in critically ill patients with the Middle East respiratory syndrome. Influenza Other Respir Viruses 2019; 13:382-90. [PubMed] [CrossRef]

5. Alhazzani W, Møller MH, Arabi YM et al. Surviving Sepsis Campaign: guidelines on the management of critically ill adults with Coronavirus Disease 2019 (COVID-19). Intensive Care Med 2020; 46: 854-87. [PubMed][CrossRef]

6. World Health Organization. Clinical management of severe acute respiratory infection when novel coronavirus (2019-nCoV) infection is suspected: interim guidance. 
7. Gattinoni L, Chiumello D, Rossi S. COVID-19 pneumonia: ARDS or not? Crit Care 2020; 24: 154. [PubMed][CrossRef]

8. Royal College of Physicians. National Early Warning Score (NEWS)-Standardising the Assessment of Acute-Illness Severity in the NHS. London: Royal College of Physicians, 2012.

9. Claesson J, Freundlich M, Gunnarsson I et al. Scandinavian clinical practice guideline on mechanical ventilation in adults with the acute respiratory distress syndrome. Acta Anaesthesiol Scand 2015; 59: 286-97. [PubMed][CrossRef]

10. Fan E, Del Sorbo L, Goligher EC et al. An Official American Thoracic Society/European Society of Intensive Care Medicine/Society of Critical Care Medicine Clinical Practice Guideline: Mechanical Ventilation in Adult Patients with Acute Respiratory Distress Syndrome. Am J Respir Crit Care Med 2017; 195: 1253-63. [PubMed][CrossRef]

11. Gattinoni L, Chiumello D, Caironi P et al. COVID-19 pneumonia: different respiratory treatments for different phenotypes? Intensive Care Med 2020; 46:1099-102. [PubMed][CrossRef]

12. Marini JJ, Gattinoni L. Management of COVID-19 respiratory distress. JAMA 2020; 323: 2329-30. [PubMed][CrossRef]

13. Brochard L, Slutsky A, Pesenti A. Mechanical ventilation to minimize acute lung injury in acute respiratory failure. Am J Respir Crit Care Med 2017; 195: 438-42. [PubMed][CrossRef]

Publisert: 8. juli 2020. Tidsskr Nor Legeforen. DOI: 10.4045/tidsskr.20.0445

Mottatt 16.5.2020, første revisjon innsendt 3.6.2020, godkjent 23.6.2020.

Publisert under åpen tilgang CC BY-ND. Lastet ned fra tidsskriftet.no 26. april 2023. 